\title{
PEMBERDAYAAN KELOMPOK PENGGIAT PARIWISATA BUMI PERKEMAHAN PASIR BATANG DALAM PEMANFAATAN LIMBAH SAYURAN SEBAGAI PUPUK ORGANIK CAIR, DESA KARANGSARI, KECAMATAN DARMA, KABUPATEN KUNINGAN
}

\author{
Toto Supartono, ling Nasihin, Bambang Yudhayana, Ori Trian Ahsari, \\ Ilyas Dahrun dan Seno Triliantho \\ Program Studi Kehutanan, Fakultas Kehutanan Universitas Kuningan \\ Jln. Tjut Nyah Dhien No.36-A, Cijoho, Kabupaten Kuningan, Jawa Barat, Indonesia \\ E-mail: toto.supartono@uniku.ac.id
}

\begin{abstract}
The natural tourism area should not only present an element of natural beauty, but must also be able to provide education for visitors and the community through integrated activities to utilize the surrounding resources; one of which is the utilization of vegetable waste into liquid organic fertilizer. In this activity, the manufacture of liquid organic fertilizer uses an anaerobic approach that involves Kompepar natural tourism of Pasir Batang as the implementing partner. Partners have followed each phase of the activity from the time of explaining the purpose and objectives, collecting raw materials, preparing the place, cutting raw materials, watering with EM4 liquid to giving a lid to the composer. This activity shows that the implementing partners involved responded well to making liquid organic fertilizer.

Keywords: conservation, education, liquid organic fertilizer, nature tourism.
\end{abstract}

\begin{abstract}
Abstrak
Areal wisata alam sebaiknya tidak hanya menyajikan unsur keindahan alam, tetapi juga harus mampu memberikan edukasi bagi para pengunjung dan masyarakat melalui kegiatan terpadu pemanfaatan sumberdaya yang ada di sekitarnya; salah satunya adalah pemanfaatan sisa sayuran menjadi pupuk organik cair. Pada kegiatan ini, pembuatan pupuk organik cair menggunakan pendekatan anaerob yang melibatkan Kompepar wisata alam Pasir Batang sebagai mitra pelaksana. Mitra telah mengikuti setiap tahap kegiatan mulai saat penjelasan maksud dan tujuan, pengumpulan bahan baku, penyiapan tempat, pencacahan bahan baku, penyiraman dengan cairan EM4 sampai pemberian tutup pada komposer. Kegiatan ini menunjukkan bahwa mitra pelaksana yang terlibat memberikan respon yang baik terhadap pembuatan pupuk organik cair.
\end{abstract}

Kata kunci: edukasi, konservasi, pupuk organik cair, wisata alam.

\section{PENDAHULUAN}

Bumi Perkemahan Pasir Batang merupakan salah satu areal wisata yang berada di dalam kawasan Taman Nasional Gunung Ciremai (TNGC). TNGC pada mulanya berfungsi sebagai hutan produksi dan menjadi kawasan konservasi sejak tahun 2004 (Kemenhut No 42/Menhut-II/2004). Bumi Perkemahan Pasir Batang dikelola oleh Kelompok Penggerak Pariwisata Desa Karangsari Kecamatan Darma, Kabupaten Kuningan. Areal-areal yang dikembangkan untuk kegiatan wisata alam di dalam kawasan TNGC hingga saat ini masih menitikberatkan pada unsur keindahan dan potensi alam lainnya. Akan tetapi unsur edukasi belum banyak disajikan oleh para pengelola. Padahal unsur-unsur edukasi yang terkait dengan pelestarian atau pengelolaan sumberdaya alam sangat diperlukan. Adanya unsur-unsur edukasi tentunya dapat menambah ilmu pengetahuan para pengunjung dan juga diharapkan dapat merubah perilaku di lingkungan tempat tinggal dan lingkungan aktivitas sehari-hari.

Bumi Perkemahan Pasir Batang berbatasan langsung dengan areal-areal pertanian milik masyarakat, bahkan akses untuk menuju bumi perkemahan pun harus melewati 
areal-areal tersebut. Meski belum ada data kuantitatif yang akurat, areal pertanian di sekitar bumi perkemahan ini cukup luas dan memiliki potensi produksi yang sangat besar. Setiap tahun, areal-areal pertanian ditanami berbagai jenis sayuran untuk tujuan komersial. Selain menyajikan pemandangan yang uniku, kondisi ini sebenarnya memiliki peluang bagi pengembangan unsur-unsur edukasi. Potensi ini jarang dimiliki oleh areal-areal wisata yang ada di TNGC.

Berdasarkan pengamatan di lapangan, tidak semua hasil pertanian terutama yang berupa sayuran diangkut ke pasar karena busuk atau terserang hama dan penyakit sehingga ditinggalkan begitu saja di lahan-lahan pertanian atau menumpuk di tempattempat penimbangan. Hingga saat ini, para pemilik lahan belum melakukan upayaupaya pemanfaatan terhadap sayuran-sayuran yang tersisa. Padahal, sayuran-sayuran yang tidak lolos seleksi tersebut jumlahnya cukup banyak (Supartono. 2019).

Pengelola Bumi Perkemahan Pasir Batang juga belum melakukan upaya-upaya yang mengarah pada pemanfaatan sisa-sisa sayuran tersebut. Kendala utama yang dihadapi adalah terbatasnya pengetahuan tentang teknik penanganan limbah sayuran sehingga belum menjadi prioritas. Padahal, pengelola Bumi Perkemahan Pasir Batang juga menyadari bahwa pemanfaatan sisa-sisa sayuran tersebut sangat penting. Sebenarnya ada banyak solusi yang dapat dilakukan terkait dengan permasalahan di atas. Akan tetapi, untuk kegiatan ini, solusi yang ditawarkan adalah pembuatan pupuk organik cair secara anaerob dengan bahan baku sisa-sisa sayuran dan bagian sayuran lainnya seperti daun dan batang.

\section{METODE PELAKSANAAN}

\section{Lokasi dan Waktu}

Lokasi kegiatan adalah Bumi Perkemahan Pasir Batang. Lokasi ini berdasarkan administrasi pengelolaan termasuk ke dalam Seksi Pengelolaan Taman Nasional Wilayah I Kuningan, Taman Nasional Gunung Ciremai, sedangkan berdasarkan administrasi pemerintahan termasuk ke dalam Desa Karangsari, Kecamatan Darma, Kabupaten Kuningan. Tutupan lahan berupa tegakan hutan pinus tua, yang sebelumnya merupakan bagian dari hutan produksi yang dikelola oleh Perum Perhutani KPH Kuningan. Lantai hutan yang dijadikan sebagai tempat kemping terbebas dari tumbuhan bawah, sedangkan yang tidak dijadikan sebagai tempat kemping banyak ditumbuhi semak belukar dan perdu. Kegiatan lapangan dilakukan pada minggu terakhir bulan September 2019, tetapi komunikasi dengan kelompok mitra dilakukan semenjak bulan Agustus 2019.

\section{Pendekatan yang Ditawarkan}

Dalam kegiatan ini, pendekatan yang ditawarkan adalah memberdayakan Kelompok Penggerak Pariwisata dalam memanfaatkan limbah-limbah sayuran di sekitar Bumi Perkemahan Pasir Batang menjadi pupuk organik cair. Secara lebih rinci, langkah-langkah yang dilakukan dalam kegiatan ini adalah sebagai berikut:

1. Pembelian alat dan bahan. Alat dan bahan yang diperlukan berupa drum plastik yang berukuran besar, kran plastik, segel penutup drum, gula merah, dan EM4. Pembelian 
alat dilakukan di toko pertanian untuk pembelian EM4, penjual kelontongan untuk pembelian drum plastik, toko material untuk pembelian kran, dan warung tradisional untuk pembelian gula merah.

2. Pembuatan alat komposer. Pembuatan alat ini cukup sederhana, yaitu melubangi bagian bawah drum sebesar kran dan memasang kran. Sekitar $10 \mathrm{~cm}$ dari bagian dasar drum dipasang saringan untuk menyaring antara pupuk cair dan sisa-sisa sayuran.

3. Pengumpulan bahan baku. Bahan baku berupa sisa-sisa sayuran yang dikumpulkan dari lahan-lahan pertanian dan tempat penimbangan. Volume atau jumlah bahan baku disesuaikan dengan kapasitas drum.

4. Pencacahan bahan baku. Bahan baku dicacah/dipotong kecil-kecil agar dapat mengisi padat dalam drum dan mudah untuk terurai. Pencacahan dapat dilakukan dengan menggunakan pisau atau golok.

5. Pemasukan bahan baku. Sisa-sisa sayuran yang sudah dipotong-potong selanjutnya dimasukan ke dalam drum hingga penuh.

6. Pencampuran cairan tambahan dan bahan lainnya. Air gula merah, air beras, dan EM4 dicampurkan dalam satu wadah kemudian dimasukan ke dalam drum yang sudah berisi potongan-potongan sisa sayuran. Pemberian cairan campuran ke dalam drum dilakukan hingga drum tersebut penuh sehingga volume cairan campuran tersebut menyesuaikan dengan kapasitas drum.

7. Masa tunggu proses fermentasi. Masa tunggu proses fermentasi adalah satu bulan. Oleh karena itu, cairan hasil fermentasi yang sudah menjadi pupuk organik dapat dikeluarkan setelah masa fermentasi satu bulan, kemudian ditampung dalan wadah seperti jerigen dengan kapasitas menyesauikan, dan pupuk organik cair sudah dapat digunakan dengan dosis tertentu.

\section{Partisipasi Mitra dalam Pelaksanaan Program}

Kegiatan ini melibatkan Kelompok Penggiat Pariwisata Bumi Perkemahan Pasir Batang karena salah satu harapan dari kegiatan ini adalah peningkatan partisipasi masyarakat dalam pemanfaatan limbah-limbah pertanian terutama sayuran. Bentuk keterlibatan kelompok masyarakat dalam kegiatan ini adalah: pembuatan alat komposer/fermenter, pengumpulan bahan baku, pencacahan, dan pencampuran cairan.

\section{HASIL DAN PEMBAHASAN}

\section{Mitra Pelaksanaan}

Mitra Pelaksanaan kegiatan ini adalah Kelompok Penggiat Pariwisata Wisata Alam Pasir Batang yang lebih dikenal dengan sebutan Kompepar Pasir Batang. Kelompok ini terbentuk sejak tahun 2017, dipimpin oleh seorang ketua kelompok dan memiliki anggota sebanyak 35 anggota. Akan tetapi, jumlah anggota yang terlibat pada pelaksanaan ini sebanyak 10 orang. Latar belakang pendidikan kelompok adalah mulai dari sekolah dasar hingga sekolah menengah atas untuk para anggota kelompok dan perguruan tinggi atau sarajana untuk ketua kelompok. Pada saat kegiatan berlangsung, 
anggota kelompok juga banyak menyampaikan pertanyaan terkait dengan pembuatan dan manfaat dari pupuk organik cair.

\section{Proses Pembuatan Pupuk Cair}

Pelaksanaan lapangan diawali dengan penyampaian maksud dan tujuan kegiatan kepada seluruh anggota kelompok yang hadir. Pertemuan awal juga menyampaikan latar belakang dan manfaat yang diharapkan dari kegiatan ini terutama ketika pupuk organik cair sudah diproduksi. Tahap berikutnya adalah pembagian tugas kepada para anggota yang hadir, yang secara garis besar berupa: petugas yang menyiapkan tempat penyimpanan komposer dan petugas yang mengumpulkan sisa-sisa sayuran. Komposer ditempatkan di tepi lokasi camping ground, teptanya dekat pintu masuk lokasi. Karena komposer harus dilubangi dan menggunakan bor listrik sementara di bumi perkemahan belum terdapat aliran ristik, tong plastik yang berperan sebagai komposer dipersiapkan di rumah. Akan tetapi, anggota kelompok juga diberi penjelasan tata cara pembuatan komposer. Sisa-sisa sayuran yang berperan sebagai bahan baku dikumpulkan dari lahanlahan bekas penanaman sayur yang berada di sekitar bumi perkemahan.

Sisa-sisa sayuran yang sudah terkumpul dicacah/diiris kecil-kecil menggunakan pisau atau golok (Gambar 1). Irisan-irisan sisa sayuran kemudian dimasukan ke dalam komposer yang sudah ditempatkan. Pada pelaksanaan ini, sisa sayuran memenuhi komposer hingga sekitar $3 / 4$ daya tampungnya (Gambar 2). Sebelum diisi potongan sisa sayuran, bagian bawah (sekitar $10 \mathrm{~cm}$ ) dari bagian dasar komposer diberi penahan yang sudah dibuat banyak lubang. Kegiatan selanjutnya adalah melarutkan gula merah (Gambar 3) ke dalam air sekitar lima liter dan memberikan EM4 (Gambar 4) sebanyak satu botol ke dalam larutan gula. Larutan gula yang sudah diberi EM4 selanjutnya disiramkan secara merata dan perlahan ke potongan-potongan sisa sayuran yang sudah berada dalam komposer (Gambar 5).

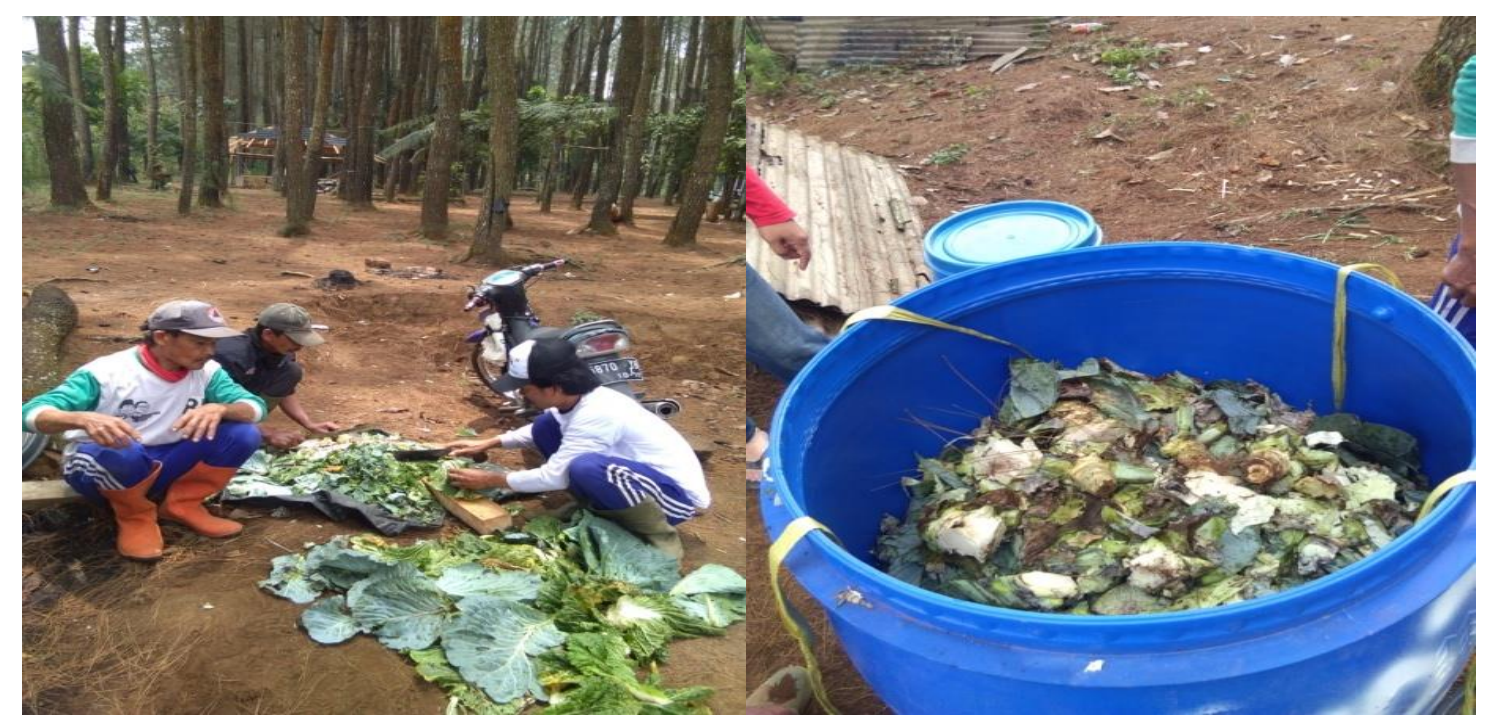

Gambar 1. Pengirisan Bahan Baku (kiri) dan Gambar 2. Bahan Baku yang Sudah Dimasukan ke Dalam Komposes (kanan) 


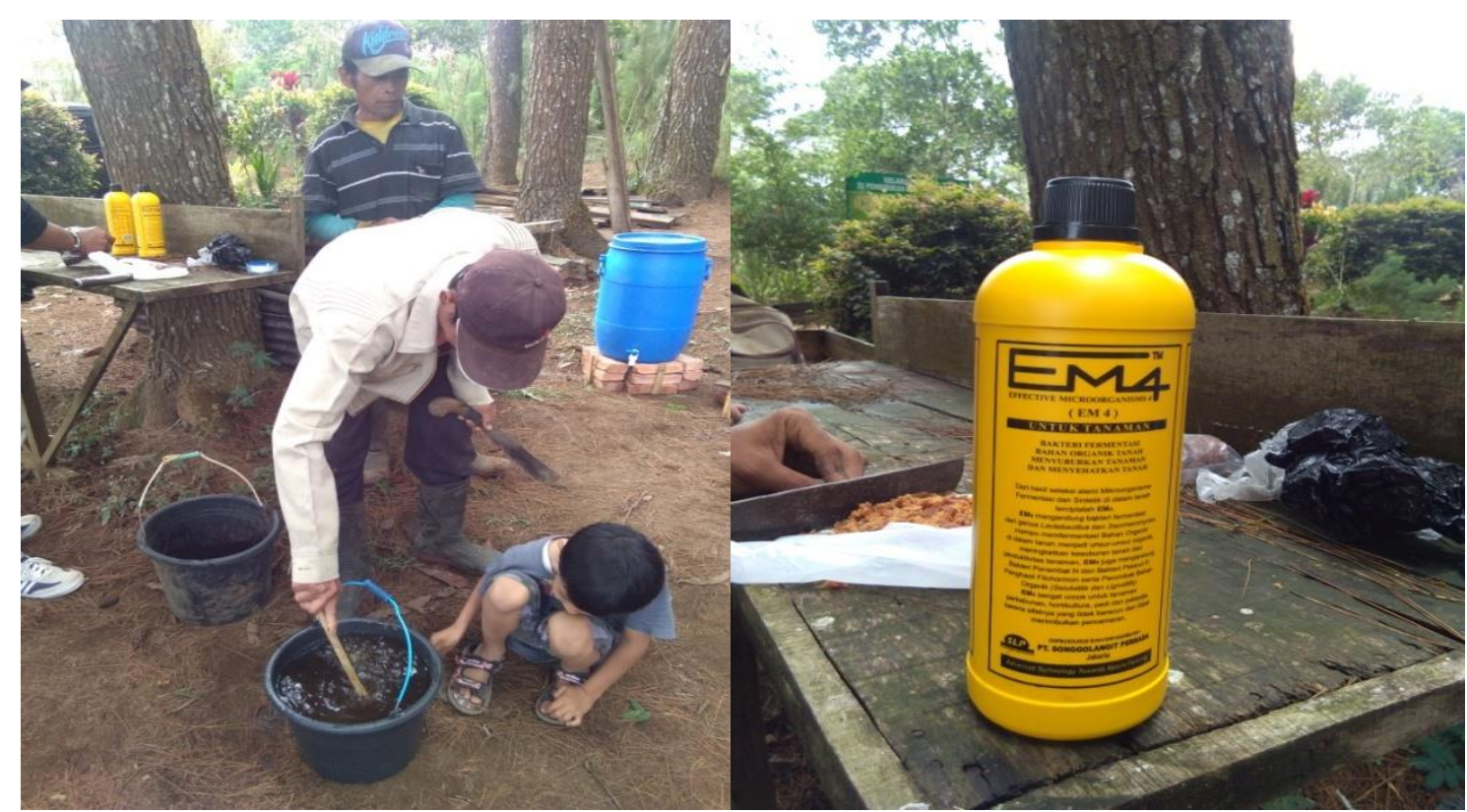

Gambar 3 Pembuatan Larutan Air Gula (kiri) dan Gambar 4 Cairan EM4 (kanan)

Tahap terakhir dari pembuatan pupuk organik cair adalah menutup komposer dan memberikan segel agar tertutup rapat sehingga tidak ada udara yang mesuk ke dalam komposer tersebut (Gambar 6).

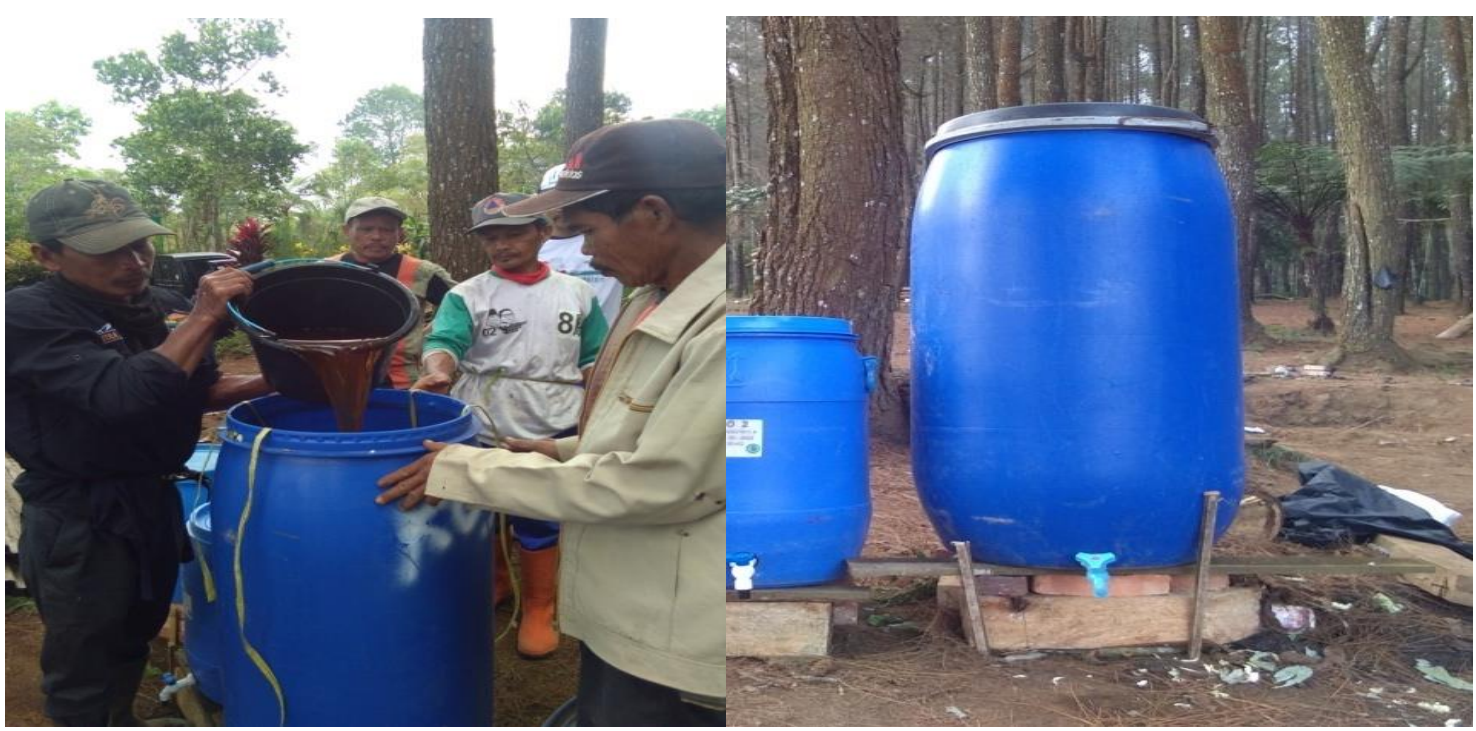

Gambar 5. Pemberian Larutan Campuran Air Gula dan EM4 ke dalam Komposer (kiri) dan Gambar 6. Komposer yang sudah Tertutup Rapat (kanan)

\section{Keterlibatan dan Respon Mitra}

Keterlibatan mitra dalam kegiatan ini sekitar satu pertiga dari total anggota kelompok. Hal tersebut karena anggota yang lainnya pada saat yang bersamaan memiliki kesibukan tersendiri seperti sedang melakukan penyiapan lahan untuk musim tanam berikutnya. Meski demikian, respon anggota kelompok yang hadir sangat baik. 
Para anggota kelompok banyak menyampaikan pertanyaan terkait dengan tata cara pembuatan pupuk organik cair secara rinci serta pemanfaatannya.

Para anggota kelompok juga menyampaikan bahwa kegiatan ini sangat penting. Ketika musim panen sayuran, tidak semua sayuran diangkut ke tempat penjualan. Sayuran yang terkena penyakit dan hampir busuk ditinggalkan di tempat dan dibiarkan membusuk. Dengan adanya pembuatan pupuk organik cair, sisa-sisa sayuran, bahkan termasuk daun dan batang, bisa dijadikan sebagai baan baku pupuk sehingga menjadi lebih bermanfaat. Beberapa anggota kelompok juga menyampaikan bahwa mereka berencana membuat pupuk organik cair di ladangnya masing-masing.

\section{Proses Pembuatan dan Penggunaan Pupuk Organik Cair}

Pupuk memiliki peranan penting dalam bagi kesuburan tanah karena dapat menggantikan unsur-unsur dalam tanah yang habis diserap oleh tanaman (Lingga \& Marsono 2019). Pupuk memiliki banyak jenis dan bentuk seperti pupuk organik cair. Penggunaan pupuk organik cair dapat meningkatkan prosentase ubi berukuran besar (Marpaung et al. 2014). Pembuatan pupuk organik cair memerlukan proses sekitar 3 4 minggu setelah pemberian larutan air gula dan pemberian cairan EM4 untuk siap pakai. Semakin lama pengomposan, semakin tinggi kandungan nitrogen dan pospor dalam cairan pupuk (Nur et al. 2016). EM4 merupakan singkatan dari Effective Microorganisms 4 dan merupakan campuran dari beberapa mikroorganisme yang sangat bermanfaat dan menguntungkan guna proses penyerapan/persediaan unsur hara didalam tanah. Mikroorganisme yang terdapat di dalam EM4 secara genetika bersifat asli bukan rekayasa (Nur et al. 2016). EM4 dapat membantu proses fermentasi bahan-bahan organik dan menguraikannya termasuk sisa-sisa sayuran sehingga bisa dimanfaatkan atau diserap oleh tanaman/tumbuhan. Pemberian larutan gula bertujuan untuk mengaktifkan mikroorganisme EM4 karena larutan gula tersebut dapat berperan sebagai bahan makanan bagi mikroorganisme.

Sebagaimana disebutkan di atas, komposer ditutup secara rapat bertujuan agar udara dari luar tidak masuk ke dalam komposer. Hal ini karena pembuatan pupuk ini menggunakan sistem anaerob (tidak membutuhkan oksigen). Sistem anaerob memiliki kelebihan, yaitu cairan yang diperoleh akan beraroma wangi seperti wangi air tape; berbeda dengan sistem aerob yang cairannya akan memberikan aroma busuk yang menyengat. Pupuk cair yang terbentuk dapat digunakan setiap hari maupun setiap minggu dengan cara penyiraman. Untuk penggunaan setiap minggu, dosis yang digunakan sekitar $250 \mathrm{ml}$ pupuk organik cair untuk sekitar 14 - 15 liter air. Untuk penggunaan setiap hari, dosis yang digunakan sekitar $250 \mathrm{ml}$ untuk sekitar 25 liter air.

\section{Implikasi Kegiatan}

Adapun implikasi kegiatan Pemberdayaan Kelompok Penggiat Pariwisata Bumi Perkemahan Pasir Batang Dalam Pemanfaatan Limbah Sayuran Sebagai Pupuk Organik Cair, yaitu diantaranya : 
a. Peningkatan nilai tambah limbah pertanian yaitu sebelum diangkut ke pasar, sayuran hasil pertanian disortir terlebih dahulu dan yang tidak lolos sortir akan ditinggalkan sehingga berserakan menjadi barang yang tidak berguna. Pembuatan pupuk organik cair telah merubah barang-barang yang tadinya tidak bermanfaat menjadi barang yang bermanfaat sehingga menjadi nilai tambah dari batang-barang sisa bagi para petani.

b. Penambahan sarana wisata yaitu Sarana Bumi Perkemahan Pasir Batang saat ini masih terbatas. Sarana yang ada adalah mushola, gazebo untuk pertemuan, toilet, camping ground, panggung selfi dan melihat pemandang, flying fox, dan ayunan. Keberadaan sarana pengolahan limbah sayuran sebagai pupuk organik cair dapat menambah sarana di bumi perkemahan tersebut. Sarana tersebut dapat menjadi sarana pembelajaran bagi para pengunjung bagaimana mengelola limbah menjadi barang yang bermanfaat.

c. Pengurangan penggunaan pupuk kimia yaitu Selama ini, para petani di sekitar Bumi Perkemahan Pasir Batang dalam menanam sayuran dan komoditas pertanian banyak menggunakan pupuk kimia dan pupuk kandang. Selain kedua jenis pupuk tersebut terdapat juga jenis pupuk, seperti pupuk organik cair. Para petani di lokasi tersebut belum menggunakan pupuk organik cair karena jenis pupuk tersebut belum populer di kalangan mereka. Dengan adanya pupuk organik cair, jenis tersebut dapat menjadi alternatif bagi para petani sehingga penggunaan pupuk kimia dapat dikurangi dan lebih ramah lingkungan. Pada akhirnya, penggunaan kontaminasi tanah oleh zat-zat kimia secara bertahap menjadi pulih.

d. Peningkatan pengetahuan yaitu Pemanfaatan limbah sayuran menjadi pupuk organik cari diharapkan dapat meningkatkan pengetahuan, baik bagi pengunjung maupun para petani yang memiliki lahan di sekitar Bumi Perkemahan Pasir Batang. Selama ini, pengetahuan pupuk non kimia atau pupuk organik, baik para petani maupun masyarakat luas, umumnya masih terbatas pada pupuk kandang dan kompos. Sebaliknya, pupuk organik cair belum banyak dikenal, atau hanya sebagian kecil masyarakat saja yang sudah mengenalnya, terlebih lagi yang sudah mempraktekan masih sedikit sekali.

e. Perubahan perilaku yaitu Bertambahnya pengetahuan mengenai keberadaan pupuk organik cair diharapkan dapat merubah perilaku para pengunjung dan para petani di sekitar kawasan. Bila sisa-sisa sayuran sebelumnya diterlantarkan atau dibiarkan membusuk di tempat-tempat penimbangan atau di lahan-lahan pertanian, maka setelah mengetahui teknik pembuatan pupuk organik cair, para petani mengolahnya menjadi pupuk organik cair sehingg tidak terdapat lagi sisa-sisa sayuran. Dengan kata lain, sisa-sisa sayuran menjadi lebih bermanfaat.

f. Penghematan biaya yaitu Para petani di sekitar Bumi Perkemahan Pasir Batang selama ini dalam penggunaan pupuk baik kimia maupun pupuk kandang harus membeli dari para penjual. Penggunaan pupuk organik cair dapat mengurangi pupuk kimia dan pupuk kandang. Dengan demikian, biaya yang digunakan untuk pembelian pupuk akan berkurang sehingga petani dapat melakukan penghematan. 
Kelebihan lainnya dari pembuatan pupuk organik cair adalah bahan baku pupuk dapat diperoleh dari lahan masing-masing atau lahan para petani itu sendiri.

\section{SIMPULAN}

Pembuatan pupuk organik cair berbahan baku sisa-sisa sayuran mendapatkan respon positif dari anggota mitra yang menandakan bahwa kegiatan ini sangat penting dan harus terus dipantau. Pembuatan pupuk organik cair sebenarnya sangat mudah dilakukan karena prosesnya yang sangat sederhana serta bahan dan alat yang dibutuhkan berada di lingkungan sekitar sehingga sangat mudah untuk diperoleh. Pembuatan pupuk organik cair dapat mendukung pertanian ramah lingkungan dan pertanian sehat sehingga perlu didukung oleh banyak pihak.

\section{SARAN}

Kegiatan pembuatan pupuk organik harus dilakukan secara bekelanjutan dan melibatkan semua pihak sehingga hasilnya menjadi optimal serta peningkatan pemasaran terhadap konsumen-konsumen yang berpotensi sehingga pembuatan pupuk organik dapat meningkatkan perekonomian masyarakat.

\section{UCAPAN TERIMA KASIH}

Ucapan terima kasih disampaikan kepada Universitas Kuningan melalui Lembaga Penelitian dan Pengabdian Kepada Masyarakat yang sudah memberikan bantuan dana untuk kegiatan pengbadian ini. Ucapan terima kasih juga disampaikan kepada Kelompok Penggiat Pariwisata Wisata Alam Pasir Batang atas kerjasamanya dalam kegiatan ini serta Balai Taman Nasional Gunung Ciremai yang sudah memberikan ijin untuk melaksanakan kegiatan di dalam areal kerjanya.

\section{DAFTAR PUSTAKA}

Kementrian Kehutanan Republik Indonesia. 2004. Keputusan Menteri Kehutanan Nomor : 42/Menhut-II/2004 tentang Penunjukan Kawasan Lindung Kelompok Hutan Gunung Ciremai menjadi Taman Nasional. Jakarta: Kementrian Kehutanan.

Lingga P, Marsono. 2019. Panduan Lengkap Memupuk Tanaman Organik dan Anorganik. Jakarta: Penebar Swadaya.

Marpaung AE, Karo B, dan Tarigan. Pemanfaatan pupuk organik cair dan teknik penanaman dalam peningkatan pertumbuhan dan hasil kentang (the utilization of liquid organic fertilizer and planting techniques for increasing the potato growth and yielding). Jurnal Hortikultura. 24(1):49-55.

Nur T, Noor AR, Elma M. 2016. Pembuatan pupuk organik cair dari sampah organik rumah tangga dengan penambahan bioaktivator EM4 (effective microorganisms). Konversi: 5(2): 1-12.

Toto Supartono dan Bambang Yudayana. 2019. Partisipasi Masyarakat dalam Peningkatan Pertumbuhan Permudaan Alami di Bumi Perkemahan Pasir Batang 
Empowerment : Jurnal Pengabdian Masyarakat, e-ISSN 2598-2052

Vol. 02 Nomor 02. 2019. 74-82.

Taman Nasional Gunung Ciremai Desa Karangsari, Kecamatan Darma, Kuningan, Jawa Barat. Empowerment : Jurnal Pengabdian Masyarakat, e-ISSN 2598-2052 Vol. 02 Nomor 01. 2019.38-45. 